\title{
Challenges in producing compassionate health workers
}

The invited review by Saroj Jayasinghe (SJ) published in the last issue of CJMS is timely and thought provoking [1]. As the author admits, though compassion is recognised as an important attribute of a health worker, it is evident in low levels among those who should display it. I see two main reasons why it is difficult to inculcate compassion among health workers.

Firstly, compassion cannot be cultivated for a specific purpose only. Studying, reading, courtesy, etiquette, punctuality, non-smoking, obedience, respect, etc. can be practiced during the professional life while ignoring them in the social life and family life of the individual. However, compassion cannot be practiced in a similar fashion. Therefore, if an individual wants to be compassionate he/ she should display it in his/ her day to day life too in same proportions. In a society where hatred, greed, arrogance, competitiveness and selfishness are common and expectations of success, financial stability, fame and luxurious lifestyle are the norms in family and social life, individuals find it hard to develop compassion to significant levels in their family and social lives. As a result they find it difficult to cultivate compassion in professional life too.

Secondly compassion cannot be developed in isolation. To develop compassion in a progressive manner, one needs to develop other attributes like generosity, egolessness, truthfulness, mindfulness, simplicity, equanimity, contentment and wisdom. Each of these positive attributes help in the growth of others. If so, one might say why not try to develop all these attributes among medical personnel as these are good qualities which will improve patient care. But there is a hitch! If an individual develops all these positive qualities in life, he or she will shun egotism, fame, competitiveness, academic achievements, administrative responsibilities, excessive financial profits and inequity. Unfortunately employers of medical personnel, be public or private, expect all their employees to have these ambitions in varying proportions. Therefore it blocks the growth of compassion among ordinary medical personnel. Those few who will be bold enough to develop the above mentioned positive attributes in union will be considered as eccentric and failures by the medical fraternity.

I have given two core reasons why we have found it difficult to inculcate compassion among medical personnel in significant proportions. I feel researchers and academics like SJ who tire hard to build positive attributes among health workers for the benefit of patients will have to be contend with low levels of compassion among us in the medical profession unless the society is ready for a paradigm shift in thinking, behaviour and norms.

\author{
Anuruddha M Abeygunasekera \\ Urological Surgeon \\ Colombo South Teaching hospital \\ amabey@sltnet.lk
}

http://orcid.org/0000-0003-3427-6796

DOI:

http://doi.org/10.4038/cjms.v54i2.4823

\section{References}

1. Jayasinghe Saroj. Integrating compassion to clinical care: a review of an emerging 'science'. Ceylon Med J Sci 2017;54:3-8 


\section{A reply: Challenges in producing compassionate health workers}

My sincere thanks to Dr. Anuruddha Abeygunasekera for highlighting two hypotheses on difficulties encountered when promoting compassion in the profession [1]. I partly agree that a professional's behaviour or lack of compassion will reflect some of the ills of society(s) he/ she lives in, and that compassion cannot be learnt in isolation. However, we have to begin (or accelerate) this uphill task of developing compassionate health workers, and I urge that we commence this process in whatever way we could.

health, decrease trust between individuals and promote violence [4]. As academics, we need to challenge this status quo, explore paradigm shifts, and consider novel concepts such as 'Caring Economics' $[5,6]$.

In relation to teaching of compassion, the difficulties in teaching it in isolation is similar to challenges faced when teaching biomedical subjects. We still debate whether basic sciences should be integrated with each other and clinical sciences, or learnt in different silos. Similarly, there is no ideal package of teaching compassion and we could try teaching it in isolation, or combined with other attributes mentioned by AA (e.g. generosity, egolessness, and contentment).

We cannot contend with low levels of compassion and we need to do something! It is sad that professionals and academia in Sri Lanka have failed to tap its very own historical, religious, and cultural roots that have a wealth of values and practices based on compassion, altruism and mindfulness.

Saroj Jayasinghe

Professor of Medicine

Head, Department of Medical Humanities

http://orcid.org/0000-0003-1460-6073
I see at least two ways to address the ills of society: one approach is to change one-self to become a more compassionate person and begin the process of changing the world. This approach is described in detail in a well referenced text of 849 pages [2]. The second is to promote establishing more compassionbased systems in society. This will require us to recognize how the prevalent profit motive to structure society leads to institutionalized greed and unacceptable inequalities [3] and how these widening socio-economic inequalities could impact adversely on

\section{References}

1. Letters to editor: Challenges in producing compassionate health workers. CJMS 2017: Vol 54 (2);

2. Altruism: The Power of Compassion to Change Yourself and the World. Matthieu Ricard. Little Brown and Company, New York, 2016

3. The Price of Inequality: How Today's Divided Society Endangers Our Future. Joseph E. Stiglitz. W. W. Norton Company, New York, 2013

4. The Spirit Level: Why More Equal Societies Almost Always Do Better. Richard G. Wilkinson and Kate Pickett. Allen Lane, London, 2009

5. Quest for a New Paradigm in Economics A Synthesis of Views of the New Economics Working Group. Jacobs G, Swilling, M, Nagan WP, Gill B, Morgan J. Cadmus 2017;310-45.

6. Caring Economics. Conversations on Altruism and Compassion, Between Scientists, Economists, and the Dalai Lama. Tania Singer, Matthieu Ricard. Picador Books. London, 2015 